\title{
PENGARUH VARIASI TEMPERATUR TERHADAP KARAKTERISTIK FISIKA, KIMIA, DAN BIOLOGI YOGHURT SUSU JAGUNG
}

\author{
Nurhaida Widiani, Gres maretta, dan Syarifah Setianingrum \\ Program Studi Pendidikan Biologi, Fakultas Tarbiyah dan Keguruan \\ UIN Raden Intan Lampung, Jalan Endro Suratmin 1 Bandar Lampung \\ email:n.widiani@yahoo.com
}

Diterima: 16 Mei 2017. Disetujui : 19 Juni 2017. Dipublikasikan: 29 Juni 2017

\begin{abstract}
Abstrak: Jagung manis (Zea mays L. Saccharata) atau sweet corn merupakan jenis jagung yang belum lama dikenal dan baru dikembangkan di Indonesia. Selama ini masyarakat mengolah jagung menjadi jagung rebus, jagung bakar, atau dibuat kue. Penganekaragaman produk makanan dengan bahan baku jagung perlu dilakukan untuk memberi nilai tambah bagi jagung. Untuk itu dalam penelitian ini jagung akan diolah menjadi yoghurt. Agar dapat diterima dipasaran yoghurt susu jagung yang dihasilkan harus memenuhi syarat mutu berdasarkan kriteria Standar Nasional Indonesia (SNI 2981:2009). Temperatur merupakan salah satu faktor penting dalam proses fermentasi. Dalam penelitian ini menggunakan variasi temperatur untuk menemukan temperatur yang paling tepat untuk pembuatan yoghurt yang berkualitas. Berdasarkan penelitian yoghurt susu jagung yang paling memenuhi syarat mutu berdasarkan kriteria SNI adalah yoghurt yang difermentasi pada temperatur $44^{\circ} \mathrm{C}$. Yoghurt yang dihasilkan memiliki tekstur yang agak kental, bau khas yoghurt, rasa asam, dan warna kuning. Yoghurt yang dihasilkan memiliki kadar protein 2,052 \% - 2,072 dan aman dari kontaminasi coliform.
\end{abstract}

Kata kunci: Yoghurt, Jagung, Fermentasi, Temperatur.

\section{PENDAHULUAN}

Jagung merupakan salah satu hasil pertanian di Indonesia. Beberapa suku di Indonesia menjadikan jagung sebagai makanan pokok. Jagung biasa diolah menjadi jagung rebus, jagung bakar, atau diolah menjadi kue. Selain itu jagung juga biasa diolah menjadi tepung jagung dan minyak jagung. Penganekaragaman jagung menjadi produk olahan lain perlu dilakukan untuk memberikan nilai tambah dan manfaat dari jagung, salah satunya dapat dikembangkan menjadi yoghurt susu jagung.

Jagung manis (Zea mays L. Saccharata) atau sweet corn merupakan jenis jagung yang belum lama dikenal dan baru dikembangkan di Indonesia. Sweet corn semakin popular dan banyak dikonsumsi karena memiliki rasa yang lebih manis dibandingkan jagung biasa, aroma lebih harum, dan mengandung gula sukrosa serta rendah lemak sehingga baik dikonsumsi bagi penderita diabetes.

Kandungan gizi jagung cukup baik, dalam 100 gram jagung mengandung $2 \mathrm{mg}$ vitamin $\mathrm{C}$ dan $3 \mathrm{mg}$ kalsium. Jagung juga mengandung vitamin serta nutrisi yang penting bagi tubuh. Jagung merupakan salah satu jenis bahan makanan yang mengandung karbohidrat, memiliki kalori dan protein yang hampir sama dengan biji padi (Novrianti et al, 2013). Karbohidrat, protein, dan vitamin merupakan nutrisi yang diperlukan untuk pertumbuhan bakteri asam laktat. Sehingga jagung 
dapat diolah menjadi yoghurt. Yoghurt merupakan produk fermentasi berbentuk semi solid yang dihasilkan melalui proses fermentasi dengan memanfaatkan bakteri asam laktat. Dalam proses pembuatan yoghurt menggunakan kultur campuran bakteri asam laktat Lactobacilus bulgaricus dan Streptococcus thermophilus (Hidayat et al, 2006). Selama proses fermentasi akan terjadi perubahan kimiawi sehingga menghasilkan produk dengan aroma, rasa, dan tekstur yang khas.

Penelitian yang dilakukan oleh Lismayana Hansur, Yoghurt dibuat dari campuran jagung manis dan susu bubuk skim. Bahan-bahan itu kemudian dicampurkan dengan organisme probiotik sebanyak 5\% untuk membantu proses fermentasi. Dari penelitian ini dihasilkan yoghurt dengan tingkat kekentalan 17\%, tingkat keasaman $0,9 \%$, gula $4 \%$, nokulan $8,9 \times 10^{8} \mathrm{CFU} /$ gram jumlah sel hidup, kadar air $82,48 \%$, protein 3,54\%, lemak $0,48 \%$ dan serat kasar $0,86 \%$ (Novrianti et al, 2013).

Pati merupakan karbohidrat kompleks terbanyak yang terdapat dalam jagung. Pati tidak dapat dijadikan sumber karbon bagi bakteri asam laktat (BAL). kandungan glukosa, fruktosa, dan sukrosa pada jagung manis tidak terlalu banyak. Untuk itu perlunya penambahan gula sebagai sumber karbon dalam bentuk lain. Gula yang dapat digunakan oleh bakteri asam laktat dalam bentuk glukosa, sukrosa, laktosa, atau fruktosa. Madu dapat digunakan sebagai sumber karbon bagi bakteri asam laktat. Madu mengandung fruktosa $41 \%$, glukosa 35\%, dan sukrosa 1,9\%. Madu juga mengandung vitamin A, B1, B2, B3, B5, B6, C, D, E, $\mathrm{K}$, beta karoten, flavonoid, asam fenolik, asam nikotinat, mineral dan garam atau zat lain seperti zat besi, sulfur, magnesium, kalsium, kalium, khlor, natrium, fosfor dan sodium serta antibiotika dan enzim pencernaan (Novrianti et al, 2013). Berdasarkan penelitian Novrianti dkk (2013), penambahan madu 2\% - 10\% pada pembuatan yoghurt menggunakan jagung mutiara (Zea mays Indurata) telah memenuhi standar SNI.

Lamanya waktu fermentasi dan temperatur merupakan faktor penentu dalam proses fermentasi yoghurt. Suhu optimum untuk bakteri Lactobacilus bulgaricus adalah $42-45^{\circ} \mathrm{C}$ dan suhu optimum untuk Streptococcus thermophilus adalah $38-42^{\circ} \mathrm{C}$ (Hidayat et al, 2006). Pada penelitian yang akan dilakukan, fermentasi yoghurt susu jagung ini menggunakan temperatur yang berbeda-beda. Penelitian ini bertujuan untuk mengetahui temperatur yang sesuai untuk menghasilkan yoghurt susu jagung yang memenuhi syarat mutu Standar Nasional Indonesia (SNI 2981:2009)

\section{METODE PENELTIAN \\ Tempat dan Waktu Penelitian}

Penelitian ini dilaksanakan di Laboratorium Biologi IAIN Raden Intan Lampung dan laboratorium Fisika dan Kimia Pangan Politeknik Negeri Lampung. Penelitian dilaksanakan pada bulan September 2016.

\section{Jenis Penelitian}

Penelitian ini merupakan penelitian eksperimen. Rancangan yang digunakan dalam penelitian ini yaitu menggunakan Rancangan Acak Lengkap (RAL) dengan 3 perlakuan adapun 3 perlakuan ini adalah, $38^{\circ} \mathrm{C}, 42^{\circ} \mathrm{C}$, dan $44^{\circ} \mathrm{C}$, 
selama 6 jam. ${ }^{1}$ Masing-masing perlakuan terdiri dari lima kali pengulangan, sehingga terdapat $3 \times 5=15$ satuan percobaan.

\section{Alat dan Bahan}

Alat yang digunakan dalam penelitian ini adalah Inkubator, blender, kompor, panci, saringan, baskom, kapas, gelas kimia, gelas baker, erlenmeyer, timbangan digital, thermometer, labu kjedhal, pemanas listrik, lemari asam, tabung durham, botol percobaan, alat titrasi, pipet tetes, dan $\mathrm{pH}$ meter. Sedangkan bahan yang digunakan dalam penelitian ini adalah jagung manis, air, kultur bakteri Streptococcus thermophillus dan Lactobacillus bulgaricus, kaldu laktosa steril, media Brilliant Green Lactase Bilebroth (BGLB), biuret, aquades, susu skim, gula pasir, indikator penolpthalein (PP), $\mathrm{Na}_{2} \mathrm{SO}_{4}$ anhidrat, $\mathrm{H}_{2} \mathrm{SO}_{4}, \mathrm{CuSO}_{4}$, $\mathrm{HCl} 0,1 \mathrm{~N}, \mathrm{~K}_{2} \mathrm{~S}$, dan larutan $\mathrm{NaOH} 0,1 \mathrm{~N}$.

\section{Cara Kerja}

\section{Pembuatan Susu Nabati Jagung}

Jagung dibersihkan kemudian direbus selama 10 menit. Perebusan dilakukan untuk membuat biji jagung menjadi lunak ketika digiling dengan mesin blender, perebusan dilakukan hingga suhu $100^{\circ} \mathrm{C}$. Selanjutnya biji jagung dipipil. Jagung yang sudah dipipil diblender dengan air hangat. Bubur jagung yang dihasilkan kemudian disaring menggunakan kain saring.

\section{Fermentasi Yoghurt}

Susu nabati jagung selanjutnya difermentasi. Susu nabati jagung dimasukan kedalam botol perlakuan sebanyak $100 \mathrm{ml}$. Susu skim sebanyak $20 \%$ dimasukan ke masing-masing botol perlakuan kemudian dihomogenkan. Setelah homogen, botol tersebut dipasteurisasi pada suhu $80^{\circ} \mathrm{C}$ selama 15 menit dan dinginkan hingga mencapai $40-42^{\circ} \mathrm{C}$. Jika sudah dingin, stater Lactobacillus bulgaricus dan Streptococcus thermopillus diinokulasi ke susu. Selanjutnya susu jagung dimasukan ke dalam gelas pelastik dan diinkubasi sesuai dengan perlakuan suhu yaitu $38^{\circ} \mathrm{C}, 40{ }^{\circ} \mathrm{C}$, dan $44^{\circ} \mathrm{C}$ selama 6 jam. Setelah itu dianalisis sifat fisik, kimia, dan biologis yoghurt susu Jagung.

\section{Teknik Pengumpulan Data}

Pengumpulan data uji karakteristik secara fisika, kimia, dan biologi dilakukan pada akhir proses fermentasi. Adapun uji karakteristik yang akan diamati yaitu sebagai berikut:

\section{Uji Karakteristik secara Fisika}

Uji karakteristik secara fisika dilakukan dengan menggunakan uji organoleptik. Uji organoleptik adalah penilaian indera atau penilaian sensorik yang merupakan suatu cara penilaian dengan memanfaatkan panca indera manusia untuk mengamati tekstur, warna, bentuk, aroma, rasa suatu produk makanan, minuman ataupun obat (Fitriyono, 2014). Uji melibatkan 25 panelis yang tidak terlatih.

\footnotetext{
${ }^{1}$ Agus Santoso, Pembuatan Yoghurt Fruit dari Buah Pepaya (Carica papaya L.) (Kajian Konsentrasi Sari Buah dan Jenis Starter), Jurnal Agrina 01(01), 2014, hlm 31
} 
Tabel 1. Penilaian organoleptik uji hedonik (tingkat kesukaan) menggunakan skala 1-4.

\begin{tabular}{|c|c|}
\hline Skor & Kriteria \\
\hline 1 & Tidak suka \\
\hline 2 & Sedang \\
\hline 3 & Suka \\
\hline 4 & Sangat suka \\
\hline
\end{tabular}

a. Warna

Warna yang diamati pada percobaan ini yaitu warna sesudah susu difermentasi.

Tabel. 2 Uji Organoleptik pada Warna

\begin{tabular}{|c|c|c|}
\hline Aspek Penilaian & Skala Numerik & Skala Hedonik \\
\hline \multirow{4}{*}{ Warna } & 1 & Putih \\
\cline { 2 - 3 } & 2 & Putih Kekuningan \\
\cline { 2 - 3 } & 3 & Kuning \\
\cline { 2 - 3 } & 4 & Kuning Tua \\
\hline
\end{tabular}

b. Tekstur

Tekstur yang diamati tekstur dari hasil akhir yoghurt tersebut.

Tabel. 3 Uji Organoleptik pada Tekstur

\begin{tabular}{|c|c|c|}
\hline Aspek Penilaian & Skala Numerik & Skala Hedonik \\
\hline \multirow{4}{*}{ Tekstur } & 1 & Encer \\
\cline { 2 - 3 } & 2 & Agak Kental \\
\cline { 2 - 3 } & 3 & Kental \\
\cline { 2 - 3 } & 4 & Sangat Kental \\
\hline
\end{tabular}

c. Rasa

Rasa yang diamati yaitu rasa dari hasil akhir yoghurt tersebut.

Tabel. 4 Uji Organoleptik pada Rasa

\begin{tabular}{|c|c|c|}
\hline Aspek Penilaian & Skala Numerik & Skala Hedonik \\
\hline \multirow{4}{*}{ Rasa } & 1 & Tawar \\
\cline { 2 - 3 } & 2 & Agak asam \\
\cline { 2 - 3 } & 3 & Asam \\
\cline { 2 - 3 } & 4 & Sangat asam \\
\hline
\end{tabular}

d. Aroma

Aroma yang diamati dengan cara mencium aroma pada setiap perlakuan dari hasil akhir yoghurt tersebut.

Tabel. 5 Uji Organoleptik pada Aroma

\begin{tabular}{|c|c|c|}
\hline Aspek Penilaian & Skala Numerik & Skala Hedonik \\
\hline \multirow{4}{*}{ Aroma } & 1 & Busuk \\
\cline { 2 - 3 } & 2 & Khas Jagung \\
\cline { 2 - 3 } & 3 & Agak Khas Yoghurt \\
\cline { 2 - 3 } & 4 & Khas Yoghurt \\
\hline
\end{tabular}




\section{Uji Karakteristik secara Kimia}

Uji karakteristik secara kimia dilakukan untuk mengukur kandungan protein setelah terbentuknya yoghurt. Metode yang digunakan yaitu metode kjeldahl dengan sub metode gunning untuk mengukur protein total. Analisis kjeldahl adalah salah satu metode untuk mengukur kandungan protein total. Secara rinci metode kjeldahl meliputi tahap destruksi, destilasi, dan titrasi.

a. Tahap destruksi

Sebelum masuk tahap destruksi bahan terlebih dahulu ditimbang. 0,5 1,0g bahan ditimbang dan dimasukkan kedalam labu kjeldahl. Selanjutnya ditambahkan $1 \mathrm{~g} \mathrm{~K}_{2} \mathrm{~S}$ atau $\mathrm{Na}_{2} \mathrm{SO}_{4}$ anhidrat, dan 10-15 ml $\mathrm{H}_{2} \mathrm{SO}_{4}$ pekat. Kalau destruksi sukar dilakukan perlu ditambah 0,1 - 0,3 $\mathrm{g} \mathrm{CuSO}_{4}$. Dekstruksi dilakukan di atas pemanas listrik dalam lemari asam, mula-mula dengan api kecil, setelah asap hilang api dibesarkan. Pemanasan diakhiri setelah cairan menjadi jernih tak berwarna lagi. Kemudian dibuat perlakuan blangko. Setelah dingin ke dalam labu kjeldahl ditambahkan aquades sebanyak $100 \mathrm{ml}$ dan larutan $\mathrm{NaOH} \mathrm{45 \%} \mathrm{sampai} \mathrm{cairan} \mathrm{bersifat} \mathrm{basa.} \mathrm{Kemudian} \mathrm{labu} \mathrm{kjeldahl} \mathrm{segera}$ dipasang pada alat destilasi.

b. Destilasi

Labu Kjeldah dipanaskan sampai ammonia menguap semua, destilat ditampung dalam erlenmeyer berisi $25 \mathrm{ml}$ HCL 0,1 $\mathrm{N}$ yang sudah diberi indikator Phenolptalein $1 \%$ beberapa tetes. Distilasi diakhiri setelah tertampung destilat sebanyak $150 \mathrm{ml}$ atau setelah destilat yang keluar tak bersifat basa. Kemudian sampel dititrasi.

c. Titrasi

Sampel dititrasi dengan HCL 0,1 N sampai larutan sampel menjadi merah muda.

\section{Uji Karakteristisk secara Biologi}

Uji karakteristik secara biologi dilakukan dengan mengukur kualitatif Coliform pada yoghurt dengan metode pengujian MPN. Uji MPN dilakukan dengan dua tahap, yaitu uji Praduga (Presumtif Test) yang kemudian dilanjutkan dengna Uji Penegasan (Confirmative Test).

a. Uji Praduga

Sembilan tabung kultur disiapkan dan pada masing-masing berisi $10 \mathrm{ml}$ media cair kaldu lactose steril yang sudah dilengkapi dengan tabung durham. Letak pada rak tabung diatur dan masing-masing tabung diberi kode (A1, A2, A3, B1, B2, B3, C1, C2, C3). Sebanyak $10 \mathrm{ml}$ air sampel dituangkan ke dalam tabung kultur yang berkode A1, A2, A3. Sebanyak 1 air sampel dituangkan ke dalam tabung kultur yang berkode B1, B2, B3. Sebanyak 0,01 ml air sampel dituangkan ke dalam tabung kultur yang berkode C1, C2, C3. 9 tabung kultur tersebut diinkubasi pada suhu $37^{\circ} \mathrm{C}$ selama 1 x 24 jam. Tabung diamati apakah ada gelembung udara didalam tabung durham. Kode tabung yang positif mengeluarkan gas dicatat Mikroba penghasil gas yang tumbuh pada tabung adalah kelompok mikroba yang mampu memfermentasikan laktosa.

b. Uji Penegasan

Tabung kultur yang masing-masing berisi $10 \mathrm{ml}$ media cair BGLB steril yang sudah dilengkapi dengan tabung durham disiapkan. Letaknya pada rak tabung diatur dan masing-masing diberi kode (A1, A2, A3, B1, B2, B3, C1, 
C2, C3), sehingga jumlahnya sama dengan jumlah tabung yang positif saja. Air sampel yang sudah diinkubasikan dalam media kultur laktosa dituangkan dengan menggunakan pipet steril masing-masing sebanyak $1 \mathrm{ml}$ ke dalam tabung yang positif. Inkubasikan tabung kultur pada suhu $45^{\circ} \mathrm{C}$ selama $1 \times 24$ jam. Tabung durham diamati. Kode tabung yang positif mengeluarkan gas dicatat. Mikroba penghasil gas tumbuh pada tabung suhu tinggi $45^{\circ} \mathrm{C}$. Mikroba ini merupakan kelompok bakteri coliform fekal.

\section{Teknik Analisi Data}

Analisis data yang digunakan adalah analisi deskriptif kuantitatif. Data yang diperoleh selanjutnya dibandingkan dengan syarat mutu yoghurt berdasarkan kriteria SNI.

Tabel 6. Kriteria yoghurt berdasarkan SNI

\begin{tabular}{|c|l|c|l|}
\hline No & \multicolumn{1}{|c|}{ Kriteria Uji } & Satuan & \multicolumn{1}{|c|}{ Yoghurt Fermentasi } \\
\hline \multirow{3}{*}{1} & Penampakan & & Cairan kental - padat \\
\cline { 2 - 4 } & Bau & & Normal/ khas \\
\cline { 2 - 4 } & Rasa & & Asam/ khas \\
\cline { 2 - 4 } & Konsistensi & Homogen \\
\hline 2 & Protein & APM/g atau koloni/g & Maksimal 10 \\
\hline 3 & Bakteri Coliform & 2,7 \\
\hline
\end{tabular}

\section{HASIL PENELITIAN DAN PEMBAHASAN}

\section{Hasil Penelitian}

\section{Uji Karakteristik Secara Fisik}

Pengujian tingkat kesukaan panelis terhadap yoghurt susu jagung meliputi penilaian terhadap warna, tekstur, aroma dan rasa. Hasil penilaian panelis terhadap yoghurt susu jagung dapat dilihat pada tabel 7 .

Tabel 7. Hasil uji organoleptik dan daya terima terhadap yoghurt susu jagung

\begin{tabular}{|c|l|l|l|l|}
\hline Perlakuan & Parameter & \multicolumn{1}{|c|}{ Rata-rata } & \multicolumn{1}{|c|}{ Skala Hedonik } & Daya terima \\
\hline \multirow{4}{*}{$1\left(38^{\circ} \mathrm{C}\right)$} & Warna & 2,76 & Putih kekuningan & Sedang \\
\cline { 2 - 5 } & Penampakan & 2,04 & Agak kental & Sedang \\
\cline { 2 - 5 } & Rasa & 2,8 & Agak asam & Sedang \\
\cline { 2 - 5 } & Aroma & 2,52 & Khas jagung & Sedang \\
\hline \multirow{3}{*}{$2\left(40^{\circ} \mathrm{C}\right)$} & Warna & 3,02 & Kuning & Suka \\
\cline { 2 - 5 } & Penampakan & 2,16 & Agak kental & Sedang \\
\cline { 2 - 5 } & Rasa & 2,72 & Agak asam & Sedang \\
\cline { 2 - 5 } & Aroma & 2,55 & Khas jagung & Sedang \\
\hline \multirow{3}{*}{$3\left(44^{\circ} \mathrm{C}\right)$} & Warna & 3,16 & Kuning & Suka \\
\cline { 2 - 5 } & Penampakan & 2,12 & Agak kental & Sedang \\
\cline { 2 - 5 } & Rasa & 3 & Asam & Suka \\
\cline { 2 - 5 } & Aroma & 2,83 & Agak khas yoghurt & Suka \\
\hline
\end{tabular}

Warna yoghurt yang dihasilkan pada umumnya berwarna kuning. Pada dasarnya tidak dapat dibedakan warna kuning dari masing-masing perlakuan. 
Secara umum panelis dapat menerima warna dari yoghurt yang dihasilkan. Penilaian terhadap warna merupakan satu hal penting dalam penilaian mutu suatu produk makanan. Warna yang dihasilkan dapat menjadi indikator kesegaran atau kematangan suatu produk makanan.

Berdasarkan gambar 1. hasil rata-rata penilaian panelis terhadap warna yoghurt susu jagung mempunyai nilai tertinggi yaitu 3,16 dengan skala hedonik yaitu "kuning" dan daya terima yaitu "suka" yang didapatkan pada temperatur $44^{\circ} \mathrm{C}$, sedangkan nilai terendah yaitu 2,76 dengan skala hedonik yaitu "kuning" dan daya terima yaitu "suka" yang didapat pada temperatur $38^{\circ} \mathrm{C}$.

Berdasarkan Hasil uji analisis yang menggunakan SPSS 17 one way anova, diketahui bahwa variasi temperatur yoghurt susu jagung tidak berpengaruh terhadap warna yoghurt susu jagung. Uji analisis yang didapatkan dengan nilai $\mathrm{p}=0,270(\mathrm{p}<0,05)$.

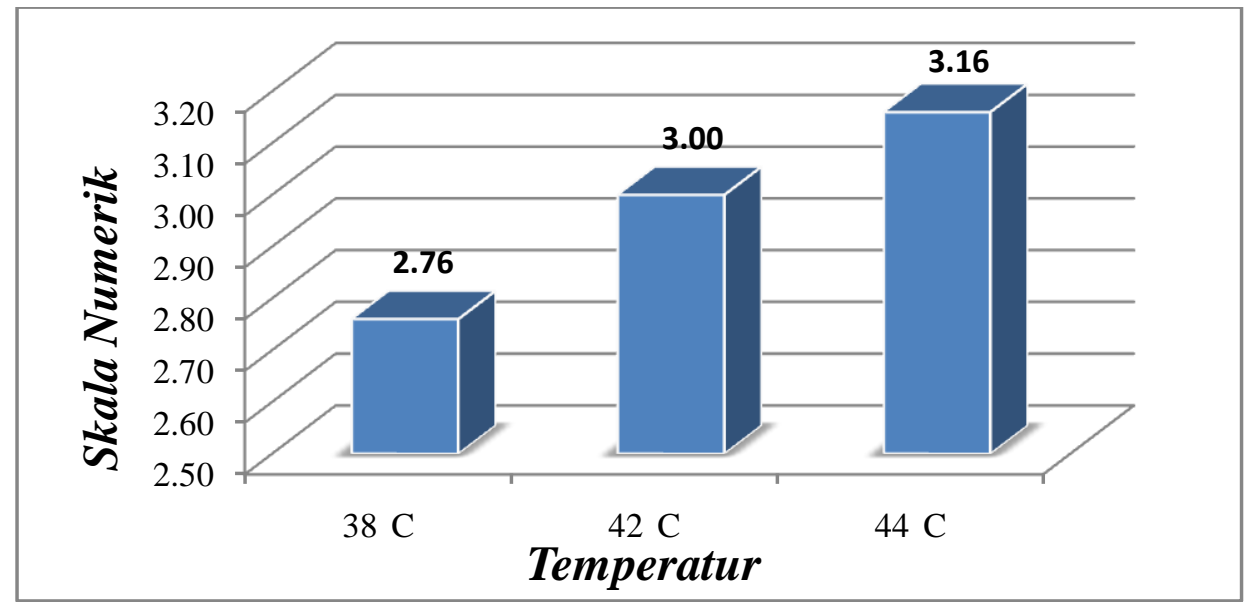

Gambar 1. Grafik Hasil Uji Organoleptik pada Warna

Penampakan (tekstur) merupakan penilaian terhadap kekentalan produk yoghurt yang dihasilkan. Penilaian terhadap penampakan dilakukan dengan indra penglihatan. Menurut Surajuddin dkk (2005) yoghurt yang baik adalah yoghurt yang kekentalannya kompak, tidak berbentuk gas serta tidak terjadi pemisahan antara cairan dan padatan. Berdasarkan penelitian yang dilakukan yoghurt yang dihasilkan agak kental. secara umum penampakan untuk semua perlakuan yoghurt cukup dapat diterima oleh panelis.

Berdasarkan gambar 2 hasil rata-rata penilaian panelis terhadap tekstur yoghurt susu jagung mempunyai nilai tertinggi yaitu 2,16 dengan skala hedonik yaitu "agak kental" dan daya terima yaitu "sedang", yang banyak didapatkan pada temperatur $42^{\circ} \mathrm{C}$, sedangkan nilai terendah yaitu 2,04 yang didapat pada temperatur $38^{\circ} \mathrm{C}$.

Berdasarkan Hasil uji analisis yang menggunakan SPSS 17 one way anova pada lampiran 1, diketahui bahwa variasi temperatur yoghurt susu jagung tidak berpengaruh terhadap tekstur yoghurt susu jagung. Uji analisis yang didapatkan dengan nilai $\mathrm{p}=0,973(\mathrm{p}<0,05)$. 


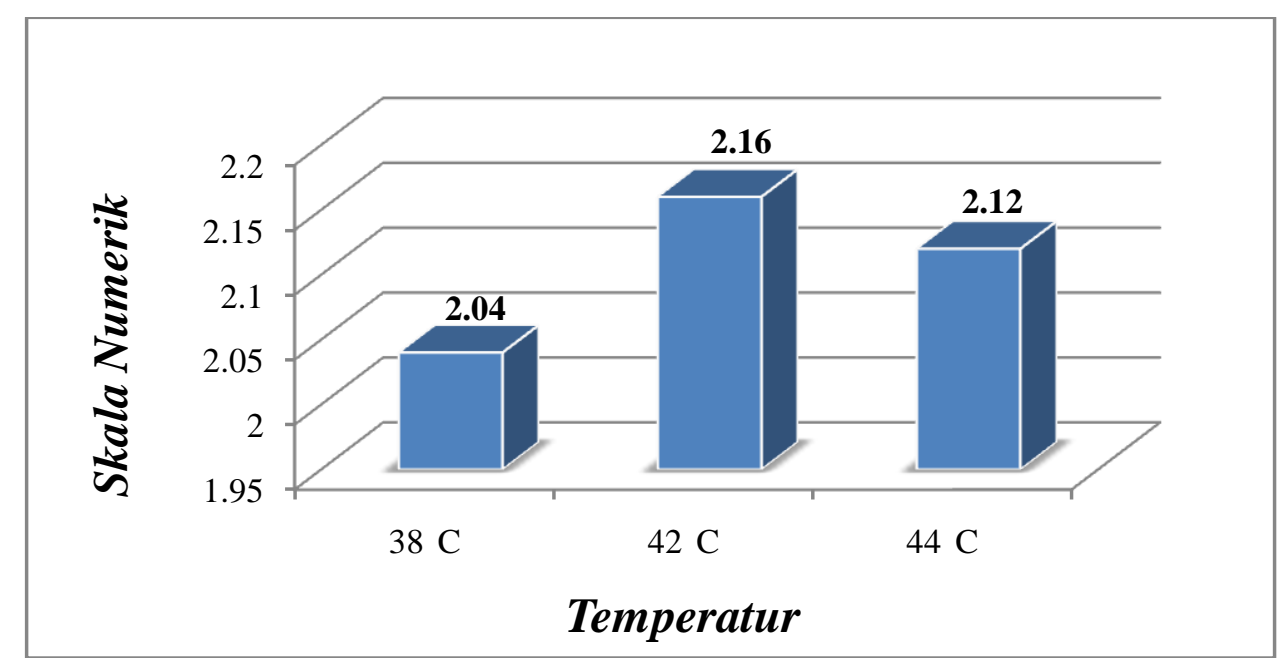

\section{Gambar 2. Grafik Uji Organoleptik pada Tektur}

Aroma merupakan parameter penting dalam penilaian organoleptik karena aroma menentukan kelezatan suatu produk makanan. Secara umum panelis dapat menerima aroma yoghurt susu jagung. Aroma yoghurt yang paling dapat diterima oleh panelis adalah aroma yang dihasilkan dari hasil fermentasi pada temperatur $44^{\circ} \mathrm{C}$.

Pada grafik organoleptik di atas menunjukkan bahwa variasi temperatur yoghurt susu jagung terhadap aroma memperoleh nilai tertinggi yaitu 3,04 dengan skala hedonik yaitu "agak khas yoghurt" dan daya terima yaitu "suka" yang didapatkan pada temperatur $44^{\circ} \mathrm{C}$, sedangkan nilai terendah yaitu 2,52 dengan skala hedonik yaitu "agak khas yoghurt" dan daya terima yaitu "suka" yang didapatkan pada temperatur $38^{\circ} \mathrm{C}$.

Berdasarkan hasil uji analisis yang menggunakan SPSS 17 one way anova, diketahui bahwa variasi temperatur yoghurt susu jagung tidak berpengaruh terhadap aroma yoghurt susu jagung. Uji analisis yang didapatkan dengan nilai $\mathrm{p}=0,183(\mathrm{p}<0,05)$.

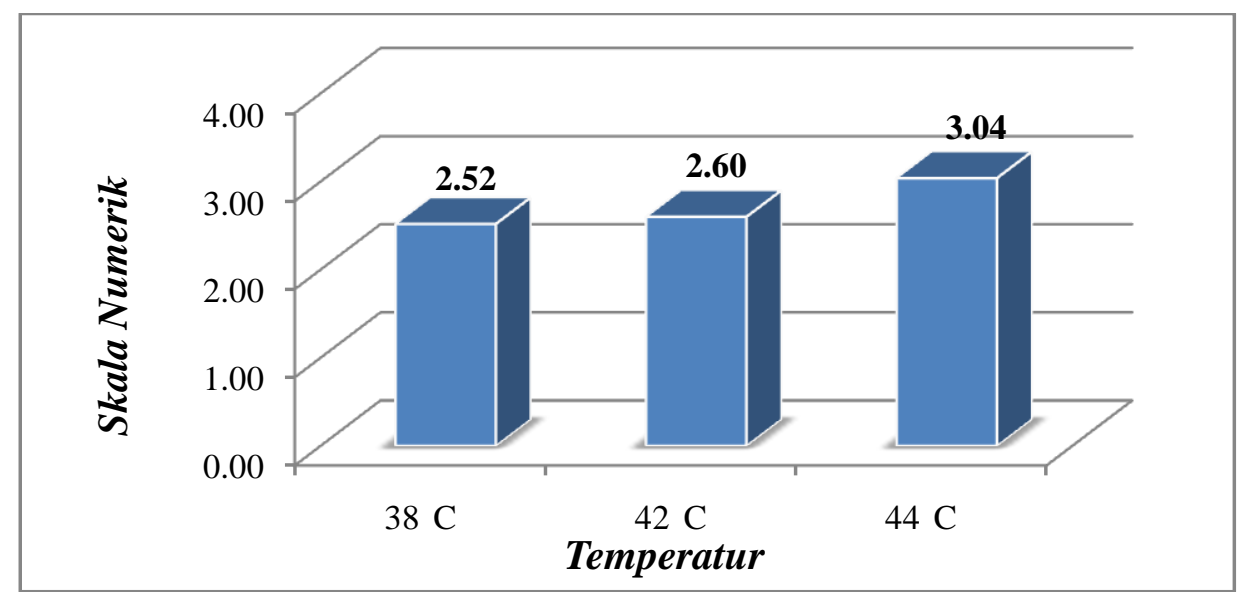

Gambar 3. Grafik Hasil Uji organoleptik Aroma

Yoghurt yang dihasilkan pada penelitian ini memiliki rasa agak asam sampai dengan asam khas rasa yoghurt. Rasa yang paling disukai oleh panelis adalah yoghurt yang difermentasi pada temperatur $44^{\circ} \mathrm{C}$ (perlakuan 3). Rasa pada 
yoghurt disebabkan karena senyawa kimia yang dihasilkaan yakni asam laktat, asetal dehid, asam asetat, dan bahan lain yang mudah menguap.

Hasil grafik organoleptik dari variasi temperatur terhadap rasa yoghurt susu jagung memperoleh nilai tertinggi yaitu 3,00 dengan skala hedonik yaitu "Asam" dan daya terima yaitu "suka" yang didapatkan pada temperatur $44^{\circ} \mathrm{C}$, sedangkan nilai terendah yaitu 2,72 dengan skala hedonik yaitu "Asam" dan daya terima yaitu "suka" yang didapatkan pada temperatur $42^{\circ} \mathrm{C}$.

Berdasarkan Hasil uji analisis yang menggunakan SPSS 17 one way anova, diketahui bahwa variasi temperatur yoghurt susu jagung tidak berpengaruh terhadap rassayoghurt susu jagung. Uji analisis yang didapatkan dengan nilai $\mathrm{p}=0,437(\mathrm{p}<0,05)$.

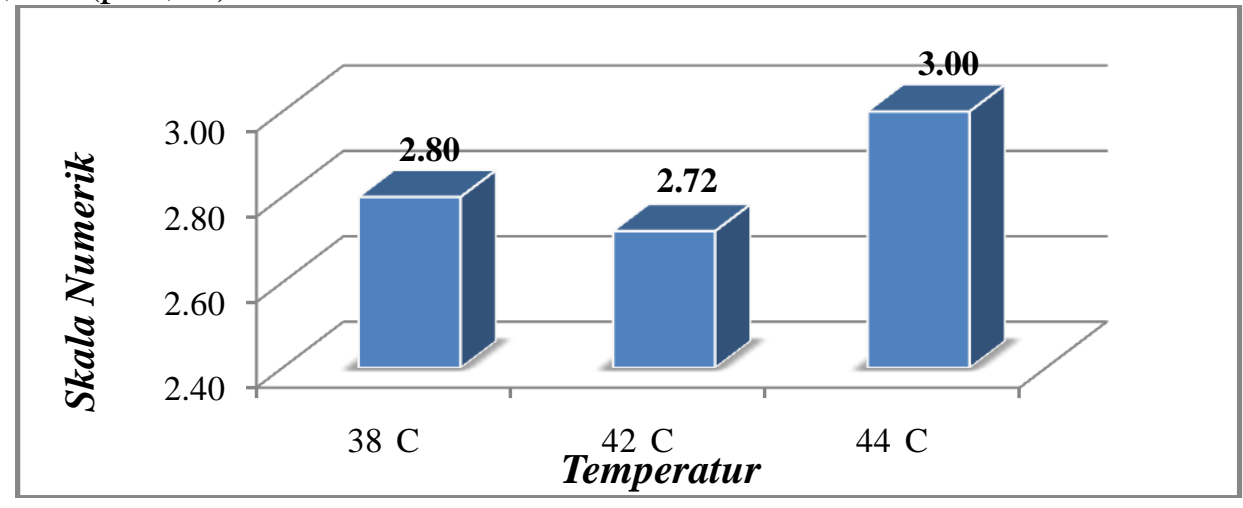

Gambar 4. Grafik Uji Organoleptik pada rasa

Berdasarkan data pada tabel 7 dapat diketahui bahwa tingkat penerimaan panelis terhadap yoghurt susu jagung yang dibuat berada dalam kriteria sedang suka. Yoghurt susu jagung yang paling diterima oleh panelis adalah yoghurt yang dibuat pada temperatur $44^{\circ} \mathrm{C}$ (perlakuan 3). Yoghurt pada perlakuan 3 berwarna kekuningan khas yoghurt, tekstur agak kental, rasa asam, serta aroma yang khas yoghurt. sedangkan penerimaan panelis terendah pada yoghurt yang dibuat pada suhu $38^{\circ} \mathrm{C}$ (perlakuan 1 ).

\section{Hasil Uji Secara Kimia}

Protein merupakan zat makanan yang sangat diperlukan oleh tubuh karena disamping berperan sebagai bahan bakar dalam proses metabolisme juga berperan sebagai zat pembangun dan pengatur. Berdasarkan uji kimia yang telah dilakukan, kadar protein yoghurt jagung dapat dilihat pada gambar 5.

Berdasarkan diagram menunjukkan bahwa temperatur yang berbeda tidak berpengaruh terhadap kenaikan kadar protein yoghurt susu jagung. Hal ini tidak sesuai dengan Herly Evanuari yang menunjukkan bahwa semakin tinggi suhu inkubator yang digunakan maka lebih cepat menurunkan keseimbangan protein kasein dalam kefir (Evanuari, 2010). Semakin rendah jumlah mikrobia yang terdapat dalam Yoghurt maka akan semakin rendah pula kandungan proteinnya karena sebagian besar komponen penyusun mikrobia adalah protein (Harastuti et al, 1994). Hal tersebut disebabkan kandungan protein telah turun akibat fermentasi asam laktat yang disebabkan mikroorganisme yang aktif dalam fermentasi. Kadar protein tertinggi pada temperatur $38^{\circ} \mathrm{C}$ dengan kadar protein 
yang dihasilkan $2,0724 \%$ dan protein terendah terdapat pada temperatur $42^{\circ} \mathrm{C}$ dengan tingkat kadar protein yang dihasilkan yaitu 2,0523\%.

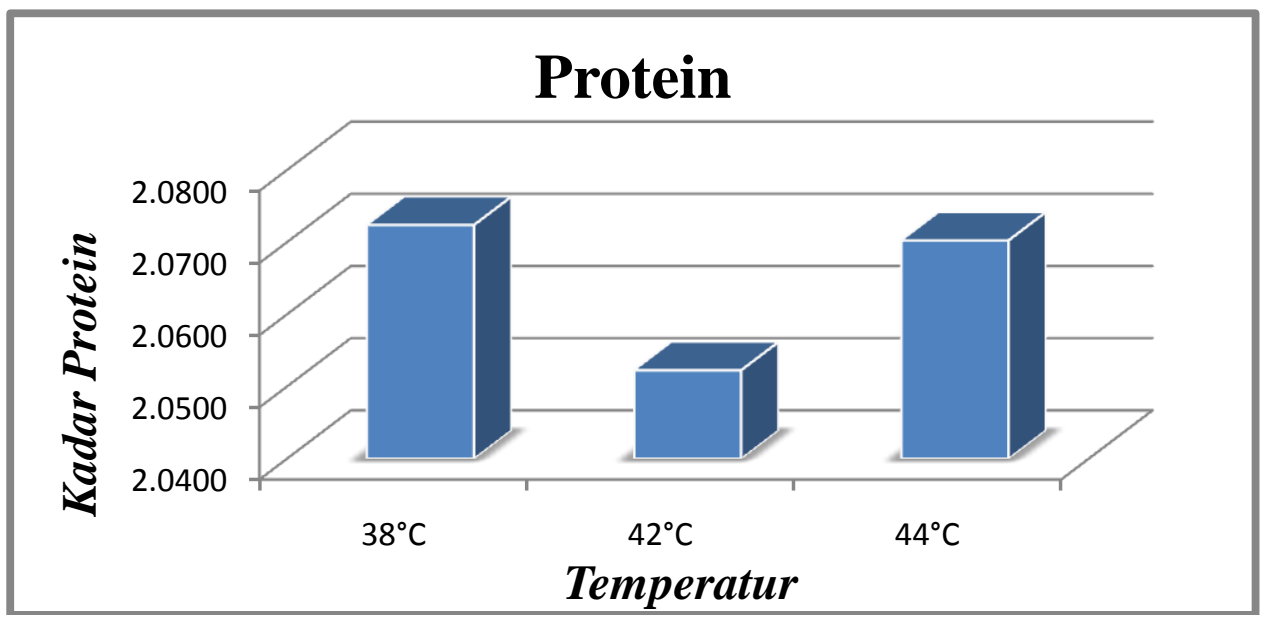

Gambar 5. Hubungan Pengaruh Temperatur Terhadap Kandungan Protein yoghurt susu jagung

Nilai kadar protein yang diperoleh berada jauh dibawah nilai kadar protein yoghurt menurut SNI 2981:2009 yang menyatakan nilai kadar protein pada yoghurt minimal 2,7\%. Menurut Winarno di dalam Sri Setyani et al menyatakan bahwa kandungan protein dapat menurun akibat pemasakan, perendaman, $\mathrm{pH}$, dan bahan-bahan kimia. (Setyani, 2009) Tamine dan Robin son dalam M. Hasir Adam mengemukakan bahwa tidak banyak perubahan kadar protein dalam yoghurt oleh pengaruh fermentasi namun yang banyak adalah perubahan komposisi protein dan dipengaruhi oleh proses pemasakan ketika perebusan jagung atau pasteurisasi (Adam dan Andy, 2011). Atau dapat juga disebabkan karena selama proses fermentasi bakteri aktif melakukan proses proteolitik dan lepolitik menjadi substansi yang bisa dimanfaatkan bakteri misalnya energi, pada mekanisme perubahan tersebut biasanya akan menghasilkan air dan secara otomatis konsentrasi protein, lemak dan laktosa dalam produk fermentasi akan menurun.

\section{Hasil Uji secara Biologi}

Pengujian secara biologi dilakukan untuk mengetahui ada atau tidak adanya bakteri Coliform dengan cara pengujian MPN yang dilakukan dua tahap, yakni uji praduga yang kemudian dilakukan dengan uji penegasan. Pengujian bakteri Coliform hanya menggunakan satu sample dari hasil uji protein yang terbaik.

Hasil pengujian secara biologi menunjukkan bahwa produk yoghurt susu jagung yang dihasilkan tidak tercemar bakteri coliform (tabel 8). Hal ini berarti bahwa produk yoghurt yang dihasilkan aman untuk dikonsumsi. Selain mengandung zat gizi agar suatu produk dapat diterima dipasaran harus bebas dari kontaminasi mikroorganisme yang bersifat merugikan. 
Tabel 8. Hasil Uji Coliform Yoghurt Susu Jagung

\begin{tabular}{|c|c|c|c|}
\hline $38^{\circ} \mathrm{C}$ & $40^{\circ} \mathrm{C}$ & $44^{\circ} \mathrm{C}$ & Keterangan \\
\hline Negatif & Negatif & Negatif & Tidak tercemar \\
\hline
\end{tabular}

Coliform merupakan suatu kelompok bakteri yang digunakan sebagai indikator adanya polusi kotoran dan kondisi yang tidak baik terhadap air dan makanan. Adanya bakteri Coliform di dalam makanan atau minuman menunjukkan kemungkinan adanya mikroba yang bersifat enteropatogenik dan atau toksigenik yang berbahaya bagi kesehatan manusia (Wahyuni, 2013). Syarat SNI mutu yoghurt (Badan Standarisasi Nasional 2009) untuk total Coliform sebesar 10. Sedangkan pada tabel 1 yang menyajikan hasil perhitungan jumlah bakteri yang dilakukan sebanyak tiga kali pengenceran $\left(10^{-3}\right)$ dengan hasil penelitian menunjukkan bahwa tidak terdapat bakteri Coliform pada setiap pengencerannya yang artinya total Coliform pada yoghurt susu jagung memenuhi standar SNI. Proses pengolahan yang higienis dan disimpan pada suhu dingin menyebabkan bakteri tidak tumbuh, karena Coliform tumbuh pada suhu $37^{\circ} \mathrm{C}$ (Zakaria, 2010).

\section{Syarat Mutu Yoghurt Berdasarkan Kriteria SNI}

Hasil uji organoleptik terhadap penampakan, aroma, rasa dan warna cukup dapat diterima oleh panelis. Untuk semua perlakuan yoghurt susu jagung yang dihasilkan mempunyai penampakan agak kental dan rasa asam khas yoghurt. Untuk bau yang paling mendekati kriteria SNI adalah yoghurt susu jagung yang difermentasi pada suhu $44^{\circ} \mathrm{C}$.

Tabel 9. Karakteristik yoghurt susu jagung berdasarkan SNI 2981:2009

\begin{tabular}{|c|l|l|l|l|l|}
\hline No & \multicolumn{1}{|c|}{ Kriteria Uji } & \multicolumn{1}{|c|}{ SNI } & \multicolumn{1}{|c|}{$38^{\circ} \mathrm{C}$} & \multicolumn{1}{c|}{$40^{\circ} \mathrm{C}$} & \multicolumn{1}{c|}{$44^{\circ} \mathrm{C}$} \\
\hline \multirow{3}{*}{1} & Penampakan & $\begin{array}{l}\text { Cairan kental }- \\
\text { padat }\end{array}$ & $\begin{array}{l}\text { Agak } \\
\text { kental }\end{array}$ & $\begin{array}{l}\text { Agak } \\
\text { kental }\end{array}$ & $\begin{array}{l}\text { Agak } \\
\text { kental }\end{array}$ \\
\cline { 2 - 6 } & Bau & Normal/ khas & $\begin{array}{l}\text { khas } \\
\text { jagung }\end{array}$ & $\begin{array}{l}\text { Khas } \\
\text { jagung }\end{array}$ & $\begin{array}{l}\text { Agak khas } \\
\text { yoghurt }\end{array}$ \\
\cline { 2 - 6 } & Rasa & Asam/ khas & $\begin{array}{l}\text { Agak } \\
\text { asam }\end{array}$ & $\begin{array}{l}\text { Agak } \\
\text { asam }\end{array}$ & Asam \\
\cline { 2 - 6 } & Konsistensi & Homogen & homogen & homogen & Homogen \\
\hline 2 & Protein & Minimal 2,7 \% & 2,072\% & $2,052 \%$ & $2,070 \%$ \\
\hline \multirow{2}{*}{3} & $\begin{array}{l}\text { Bakteri } \\
\text { Coliform }\end{array}$ & $\begin{array}{l}\text { Maksimal } 10 \\
\text { koloni/g }\end{array}$ & $\begin{array}{l}\text { Tidak } \\
\text { tercemar }\end{array}$ & $\begin{array}{l}\text { Tidak } \\
\text { tercemar }\end{array}$ & $\begin{array}{l}\text { Tidak } \\
\text { tercemar }\end{array}$ \\
\hline
\end{tabular}

Kadar protein yoghurt susu jagung yang dihasilkan kurang memenuhi syarat mutu berdasarkan SNI. Kadar protein yang dihasilkan berkisar antara 2,052 $-2,072 \%$. Untuk pengujian secara biologi, yoghurt susu jagung yang dihasilkan aman untuk dikonsumsi karena tidak ada cemaran coliform. Berdasarkan hasil pengujian secara keseluruhan yoghurt susu jagung yang dibuat cukup layak dikonsumsi karena memenuhi beberapa kriteria syarat mutu SNI 2981:2009 (tabel 9). 


\section{KESIMPULAN DAN SARAN}

Dari penelitian yang telah dilakukan dapat disimpulkan bahwa yoghurt susu jagung yang paling memenuhi syarat mutu berdasarkan kriteria SNI adalah yoghurt yang difermentasi pada temperatur $44^{\circ} \mathrm{C}$. Yoghurt yang dihasilkan memiliki tekstur yang agak kental, bau khas yoghurt, rasa asam, dan warna kuning. Yoghurt yang dihasilkan memiliki kadar protein 2,052 \% - 2,072 dan aman dari kontaminasi coliform.

\section{DAFTAR PUSTAKA}

AAK, 1993. Seri budi Daya Jagung. Yogyakarta: Kanisius.

Adnan, M. 1984. Kimia dan Teknologi Pengolahan Air Susu. Andi offset. Yogyakarta.

Arkeman Y. Yoghurt Susu Jagung Manis Kacang Hijau Sebagai Strategi Inovasi Produk Alternatif Pangan Fungsional. J. Teknik Industri Pascasarjana TIPIPB. Bogor.

Ayustaningwarno F. 2014. Teknologi Pangan; Teori Praktis dan Aplikasi. Graha Ilmu. Yogyakarta. hlm. 1

Bayu Krisnamurthi. 2010. Manfaat Jagung dan Peran Produk Bioteknologi Serealia dalam Menghadapi Krisis Pangan, Pakan dan Energi di Indonesia. Prosiding Pekan Serealia Nasional. HIm. 1

Burhan, B. 2008. Kefir Minuman Susu Fermentasi dengan Segudang Khasiat untuk Kesehatan. PT Gramedia Pustaka Utama. Jakarta.

Faisol M. 2015. Madu dan Luka Diabetik. Gosyen Publishing. Yogyakarta. Hlm 59.

Farah Riski. 2013. The Miracle of Vegetables. Agro media Pustaka. Jakarta. Hlm. 61

Finarsih F. 2014. Uji Kualitas Yoghurt Susu Sapi Dengan Penambahan Madu Dan Lactobacillus bulgaricus Pada Konsentrasi yang Berbeda. Naskah Publikasi. Universitas Muhamadiyah : Surakart. Hlm 2.

Hidayat, N., I. Nurika, dan W.A.P. Dania. 2006. Membuat Minuman Prebiotik dan Probiotik. Trubus Agrisarana. Surabaya.

Hidayat N., M.C. Padaga, dan S. Suhartini. 2006. Mikrobiologi Industri. ANDI. Yogyakarta

I. Sayuti, S. Wulandari, dan D. Kurnia Sari. 2013. Penambahan Ekstrak Ubi Jalar Ungu(Ipomoea batatas var. Ayamurasaki) dan Susu Skim TerhadapOrganoleptik Yoghurt Jagung Manis(Zea mays L. Saccharata) dengan Menggunakan Inokulum Lactobacillus acidophilus DAN Bifidobacterium sp. Prosiding semirata FMIPA Universitas Lampung.

Marvelia A., S. Darmanti, dan S. Parman. 2006. Produksi Tanaman Jagung Manis (Zea Mays L. Saccharata) yang Diperlakukan dengan Kompos Kascing dengan Dosis yang Berbeda. Buletin Anatomi dan Fisiologi XIV(2).

Nofrianti R., Azima F., Eliyasmi R. 2013. Pengaruh Penambahan Madu Terhadap Mutu Yoghurt Jagung. J. Aplikasi Teknologi Pangan 2 (2): 60-67.

Nisa Choirun Fithri. 2014. Pengaruh Sari Buah Sirsak Dan Lama Fermentasi Terhadap Karakteristik Fisik dan Kimia Yoghurt. J. Pangan dan Agroindustri 2(4): 240. 